\title{
UNHCR's Origins and Early History: Agency, Influence, and Power in Global Refugee Policy
}

\author{
GIL LOESCHER
}

\section{Abstract}

This article assesses the role and functions of UNHCR during its formative years and explores its agency, influence, and use of power in global refugee policy. During most of the Cold War, UNHCR's first four high commissioners employed delegated authority and expertise on refugee law and protection, thereby convincing states of the Office's usefulness to international stability and ensuring its survival, growth, and power. It concludes by arguing that the Office should use the lessons of this early period of its history to explore ways to exercise similar attributes today.

\section{Résumé}

Cet article établit le rôle et les fonctions du HCR durant ses années de formation et étudie son mandat, son influence et l'utilisation de son pouvoir dans le cadre de la politique mondiale relative aux réfugiés. Durant la plus grande partie de la guerre froide, les quatre premiers commissaires $d u$ HCR ont eu recours aux pouvoirs qui leur étaient délégués et à leur expertise en matière de loi sur les réfugiés et de protection des réfugiés. Ils sont ainsi arrivés à convaincre les états de la contribution apportée par le Bureau à la stabilité internationale, et à assurer ainsi sa survie, sa croissance et son pouvoir. Larticle conclut en faisant valoir que le Bureau devrait se souvenir aujourd'hui des leçons tirées de son histoire pour explorer différentes manières exploiter ces mêmes qualités.

his article addresses the agency, influence, and power of UNHCR regarding the evolution of global refugee policy during the Office's first twenty-eight years. This period coincided with the Cold War, a time of intense bipolar rivalry and a concentration of power among the United States and other Western governments.

UNHCR lacks a close history of its past operations and evolution. Much of the early history of UNHCR, particularly its role and activities in the formation of global refugee policy, its strategies and influence on policymaking, and its agency, influence, and power have been little appreciated. There is a need for strong institutional memory and for more analyses of early instances of UNHCR's agency, strategies, and power in shaping refugee policy and responding to past early refugee crises in order to inform the present.

International relations literature on global refugee policy has mostly adopted a statist perspective, which asserts that UNHCR, like all international organizations, lacks autonomy and is just a mechanism through which states act. ${ }^{1}$ Partly as a result of the influence of the realist paradigm in international relations theory, leadership in international organizations is not a broadly researched theme. The common perspective claims that UNHCR is totally dependent on donor states for funding its operations, and on host governments for permission to initiate programs on their territory. ${ }^{2}$ Therefore the Office is in no position to challenge the policies of its funders and host governments, and merely acts as an instrument of states. In fact, as the primary institution in refugee affairs, and as the world's foremost authority on refugees and displaced persons, the Office has unique authority in the humanitarian field, which at times can be utilized as influence and even power in global refugee policy. ${ }^{3}$ UNHCR has demonstrated agency and influence over the years, has been a purposive, entrepreneurial, and strategic actor with independent interests and capabilities, and has even exercised power, despite the resistance of prominent states, ${ }^{4}$ particularly during UNHCR's first twenty-eight years. 


\section{The Cold War and the Establishment of UNHCR}

When UNHCR was established in December 1950, Europe was the principal area of refugee concern for Western states, as the Cold War intensified and new refugee flows moved from east to west. While there were major refugee movements in the Middle East and in South and East Asia at this time, the Euro-centric orientation of the UNHCR reflected the foreign policy priorities of the United States, the hegemonic power within NATO and the Western alliance. The us preoccupation with reconstruction and rehabilitation in Europe after the Second World War, and the rapidly developing Cold War with the Soviet Union critically affected the lens through which the United States viewed both its own refugee policy and UNHCR.

UNHCR was created by Western governments in such a way that it would neither pose a threat to their sovereignty nor impose new financial obligations on them. States gave the Office a mandate to provide legal protection to refugees and to provide durable solutions, but no guarantee of funds to carry out material assistance programs for the refugees under its care. Having provided the bulk of funding to the United Nations Relief and Rehabilitation Agency and the International Refugee Organization during the Second World War, the United States sought to limit UNHCR to a protection role for refugees and was opposed to the Office providing material assistance to refugees.

Most significantly, American leaders considered refugee policy simply too important to permit the United Nations to control. The most important aspects of American refugee policy were maintaining international attention devoted to refugees from communist countries, encouraging emigration from the Eastern Bloc, and minimizing international appeals for assistance funds to refugees. To this end, the United States sought to limit severely the operational scope and independence of UNHCR and instead created its own American-led refugee and migration organizations, thereby enabling Washington to select, support, and control the international organizations that best reflected its own foreign policy priorities. ${ }^{5}$ The Us Escapee Program (USEP) and the Provisional Inter-Governmental Committee for the Movement of Migrants (which soon was renamed ICEM and is today IOM) were generously funded by the United States. ICEM was charged with acting as an operational organization with a broad mandate to facilitate international migration of surplus populations in Europe, including refugees. ${ }^{6}$ ICEM's activities were initially perceived by UNHCR to directly compete with and directly affect the Office's ability to define an independent role for itself.7

Despite these handicaps, by the mid-1950s UNHCR began to develop a working relationship with ICEM and other organizations and to exercise power and authority autonomously in ways unintended by states at UNHCR's creation.
To explain how this occurred, it is necessary to examine UNHCR's approach to and implementation of policy in its early years and to underscore the importance of several institutional factors that made it possible for determined early high commissioners to guide and to shape the evolution of a strong and effective organization.

The organization's historical mandate, its formal structures, the early competition it faced from other international agencies and institutions, and the internal processes and internal hierarchical decision-making of the Office itselfall influenced the direction of UNHCR refugee policy during the nearly first three decades of its existence.

First, UNHCR's 1950 Statute and the 1951 UN Refugee Convention formed the template for how UNHCR should function and how it should make global refugee policy. These instruments provided the Office with unparalleled moral authority and a monopoly on legal and protection issues regarding refugees. Most importantly, they also provided a legal basis for the Office's expansion of activities and its claims to legitimacy for its new geographic scope of activities from the mid-1950s through the late 1970s.

Second, UNHCR is an intergovernmental organization that was created by states to protect refugees and to provide durable solutions to their plight. UNHCR's Statute placed a temporal limitation on the Office's work by requiring that it could concern itself only with refugees who had fled their home countries before 1951. The Statute also made the UNHCR formally subject to the authority of the UN General Assembly and the Economic and Social Council. By placing UNHCR under the authority of the UN General Assembly, states provided a legitimate mechanism for further growth of the Office's mandate and activities. Throughout its history, particularly from the 1950s through most of the 1970s, UNHCR used General Assembly resolutions in flexible ways to define and expand its own competence, role, and autonomy in politically sensitive refugee situations. In particular, the General Assembly's “Good Offices” Resolutions of the 1950 s through the 1970 s led the Office's expansion into Africa and Asia. ${ }^{8}$ Later, during the era of Sadruddin Aga Khan, UNHCR would be delegated by the un secretary-general to act as the un lead agency for the coordination of international humanitarian assistance, not only to refugees and displaced persons, but also to victims of human-made disasters. In the process, UNHCR - with the approval of the UN General Assembly and successive UN secretaries-general-developed an enormous agenda well beyond its original mandate, greatly expanded its overall functions and authority, and became an indispensable and autonomous actor in many of the major political developments in the Global South.

Third, the international humanitarian system, the refugee regime complex, and the humanitarian marketplace within 
which UNHCR operates also affect the authority and freedom within which the Office frames its policies and programs. Despite early competition from us-led national and international refugee and migration agencies, by the mid-1950s UNHCR demonstrated to the United States and other states that it was the only international organization with the authority, operational capacity, and operational effectiveness to manage large-scale refugee protection and aid programs of geopolitical interest to the major powers.

Lastly, UNHCR's approach to policy is significantly influenced by the hierarchical structure of the Office. The 1950 Statute that established UNHCR invested all the authority of the Office in the person of the high commissioner. In interstate discussions at the time, un Secretary General Trygve Lie argued that the high commissioner should "enjoy a special status within the UN" and should also "possess the degree of independence and prestige which would seem to be required for the effective performance of his functions."9 Over the opposition of the United States, which sought to place UNHCR in the UN Secretariat and thereby control the selection of the high commissioner, the founding states decided to create an independent high commissioner directly responsible to the General Assembly. Since its inception, therefore, UNHCR has always been referred to as the High Commissioner's Office, underlining the primary importance and independence of the person of the high commissioner in UNHCR's centralized decision-making structure. Accordingly, this article is organized around the Office's first four high commissioners.

From the beginning, UNHCRhas had a top-down hierarchical decision-making and policy implementation structure. ${ }^{10}$ Thus the history and policy and institutional direction and expansion of the Office and its mandate have been influenced and shaped by individual high commissioners and their senior staff. The influence of the first four high commissioners-Gerrit van Heuven Goedhart, Auguste Lindt, Felix Schnyder, and Sadruddin Aga Khan-on the formation of the Office's early policies and achievements is particularly striking and is the focus of this article.

\section{The First Two High Commissioners: Goedhart and Lindt}

Despite initial restrictions, the first high commissioner, Gerrit van Heuven Goedhart, embarked on a strategy to lobby and to convince the United Sstates and other Western governments of UNHCR's usefulness. In an attempt to foster cooperation rather than competition, UNHCR and ICEM initiated steps to coordinate their activities in order to avoid overlap and duplication. ${ }^{11}$

At the same time, Goedhart made repeated efforts to reconfigure his Office into the leading global agency for refugees. Prior to becoming high commissioner, Goedhart had served in leading positions at the UN. Using his influence to convince former UN colleagues of the indispensability of UNHCR, he secured UN General Assembly approval to independently raise funds. A un Refugee Emergency Fund and a generous grant from the Ford Foundation enabled the Office to involve itself for the first time in overseeing assistance to NGOS, UNHCR's main operational partners, to promote the integration of refugees and long-term displaced persons (DPS) in Western Europe. Crucially, this funding also enabled UNHCR to lead in responding to an early Cold War refugee crisis in West Berlin in 1953, thereby demonstrating the Office's usefulness to the major Western powers and raising the Office's international profile.

These early successes legitimized the need for further UNHCR material assistance to refugees. In 1954, the General Assembly approved a four-year program for permanent solutions and emergency aid, as well as the creation of a United Nations Refugee Emergency Fund Executive Committee consisting of the representatives of twenty states, to oversee and direct the program. UNHCR soon demonstrated its ability to influence the policy activities of this committee through the Office's monopoly on knowledge about refugee issues and law, hosting the Secretariat within the Office, and rotating its chair. In 1955, UNHCR was awarded the Nobel Peace Prize, which further raised the international stature and profile of the Office.

Having demonstrated its ability to be proactive in raising funds and to responding to early Cold War refugee crises, UNHCR consequently was called upon to respond to the 1956 Hungarian refugee crisis. The UN designated UNHCR as the "lead agency" to direct the international emergency operation for Hungarian refugees and to coordinate the work of all voluntary agencies. The Office established a coordinating group, which included ICEM and the League of Red Cross Societies. In addition to overseeing the financing of international assistance to the refugees, UNHCR had to reconcile the priorities of the refugees, the countries of asylum and resettlement, as well as the large numbers of NGOs providing assistance to refugees.

In assuming this pivotal role, the second high commissioner, Auguste Lindt, displayed considerable innovation to overcome the temporal restrictions contained in the Refugee Convention. UNHCR's protection division maintained that the origins of the refugee crisis in Hungary could be traced to events before 1951. Lindt's Office also used its delegated expert and moral authority to argue that refugees fleeing Hungary could be recognized on a prima facie basis, rather than through individualized refugee status determination. Moreover, UNHCR's leading role in Hungary not only demonstrated its primacy among international organizations in the global refugee regime but also its emerging policy 
convergence with that of the United States and other Western states. Perhaps most important for its future growth and expansion, UNHCR also demonstrated its entrepreneurial ability to use expert knowledge in refugee law and norms in flexible and creative ways to open up opportunities for the Office to respond to new refugee crises. This is also an early example of the Office's ability to make a legal argument to justify a position the organization wanted to make for other reasons, in this case for further expansion of its activities.

The Hungarian operation demonstrated the important diplomatic role that the high commissioner could play in events at the centre of world politics. In the midst of the first major Cold War refugee crisis, the UNHCR played an essential mediating role between East and West, involving the repatriation of nearly 10 per cent of the Hungarian refugees ${ }^{12}$-an operation that was extremely controversial and was initially strongly opposed by the United States. Lindt's initiative is an early example of UNHCR exerting power within the global refuge regime to overcome the opposition of some of the world's most powerful states.

Thus, largely on its own initiatives, UNHCR grew in just a few years from a strictly non-operational agency, with no authority to appeal for funds, into an institution with an emerging long-range program emphasizing not only protection but, increasingly, material assistance. In 1958, the present Executive Committee of the High Commissioner's Program was established with twenty-five state members. This remarkable transition during a period of intense bipolar rivalry, when state interests were paramount, demonstrates that international organizations such as UNHCR frequently exhibit considerable autonomy, influence, and power in global refugee policy.

The refugee crisis in Hungary generated widespread sympathy for refugees and underscored the vital role that NGOs and local communities around the world played in UNHCR resettlement and integration programs. In response to the Hungarian emergency, UNHCR laid the groundwork for future partnerships and coalitions with NGOs in the Global South. The crisis also increased public awareness of the plight of refugees beyond Hungary, but particularly of the tens of thousands of displaced persons from the Second World War who continued to languish in DP camps in Western countries. Consequently, soon after the Hungarian crisis, a grassroots international campaign of NGOs, churches, and other public interest organizations emerged to draw attention to the plight of these and other refugees, raise funds on their behalf, and lobby the United Nations to declare a World Refugee Year. ${ }^{13}$

Lindt immediately recognized the potential of this mass social movement to raise the profile of refugees, as well as to highlight the work of UNHCR worldwide. The high commissioner also recognized that this movement provided the Office the opportunity to engage in networking at local, national, and international levels, to reach new audiences, and to develop a stronger profile among the public. In addition, this initiative offered the opportunity to raise muchneeded funds for the Office's operations, particularly in helping to resolve the protracted problem of displaced persons.

During World Refugee Year (1959-60), a transnational advocacy network of NGOs, churches, and prominent individuals that exchanged ideas and information in order to influence government policies towards refugees was established. ${ }^{14}$ When World Refugee Year ended in 1960, more than half of the displaced persons in camps in Europe had been found permanent homes in a third country, and $\$ 8$ million had been raised to clear the camps. ${ }^{15}$ While the DP problem in Europe was not fully resolved until the mid-196os, widespread social activism on behalf of refugees had galvanized public opinion and had raised the profile of both UNHCR and refugees on the global policy agenda.

World Refugee Year also coincided with major changes in international politics. Decolonization and the emergence of new states in the developing world were beginning to create massive new refugee problems. As early as the late 1950s, UNHCR under Lindt took initial steps to lay the groundwork for an expansion of its activities, from refugee crises in Europe to those in the developing world. This new approach was the "good offices" formula that involved the uN General Assembly granting UNHCR the authority to raise funds or to initiate assistance programs for refugees who did not come fully within its statutory definition but whose situation was of concern to the international community. It was applied in the first instance to enable UNHCR to raise funds for Chinese refugees in Hong Kong in the late 1950s, despite the strong opposition of the United Kingdom, the colonial power and one of the founding member states of UNHCR.

Even more significant to the Office's expansion into the developing world was its response to the Algerian refugee crisis. ${ }^{16}$ In May 1957, Tunisia requested material assistance from UNHCR for the 85,000 Algerian refugees who had fled across the border during the previous two and a half years. This was the first occasion in which UNHCR emergency assistance was requested in the developing world; thus it marked an important step in the development of the political conditions under which the Office had to act and of the functions and activities it was permitted to perform.

However, the decision to offer assistance to Algerian refugees was politically difficult and engendered an intense debate within UNHCR about its future role in the developing world. ${ }^{17}$ Some of Lindt's advisers felt that the Office should remain focused on finding solutions for the refugees caught in protracted exile in Europe. The high commissioner 
disagreed and argued forcefully that the Tunisian request presented an opportunity for UNHCR to use the new international support and goodwill that the Office had earned in its response to the Hungarian refugee emergency to confirm its position as both the leading international refugee agency and as the only international organization able to adapt to new emergencies wherever they arose. Moreover, UNHCR's decision to intervene in the Hungarian refugee emergency on the basis that all the Hungarians prima facie fell under UNHCR's mandate and did not require individual screening had established a precedent for action that was difficult for the Office to ignore in the Algerian case. Lindt feared that UNHCR would be accused of discriminatory treatment if it neglected the Algerians, and he did not want to be perceived as the "High Commissioner for European refugees only." 18 He maintained that UNHCR's mandate as defined in its Statute was worldwide, and that his Office had responsibility for dealing "with completely different people and not only refugees from communism." $19 \mathrm{He}$ was concerned that to refuse assistance to Tunisia would estrange the organization from a growing bloc of developing nations and would weaken the more favourable attitude that the Soviet Bloc had recently adopted towards the agency.

The high commissioner had to overcome strong opposition not only from senior staff members within his own Office but also from France, the colonial power in Algeria, one of the Permanent 5 members of the UN Security Council and one of the founding states of UNHCR. The French government denied the authority of the Office to give assistance in this case, claiming that Algeria was an integral part of the state of France and that the eventual solution could only be the return to Algeria of the people who had taken refuge in Tunisia and Morocco. France also feared UNHCR involvement would internationalize the crisis, and major Western governments were unwilling to oppose the French. ${ }^{20}$ Through persistent and courageous diplomacy Lindt overcame French resistance and is perhaps the clearest example of UNHCR's exercise of power in its early history.

UNHCR's action on behalf of Algerians signified a turning point in the Office's geographical scope and functions and led to a period of global and further institutional growth for the Office. In 1959, the UN General Assembly freed UNHCR from the necessity of seeking further authorizations to assist each new refugee group by giving the Office the future right to determine which groups to assist under the Good Offices function without further consultation with the General Assembly.

Lindt's assertive initiatives and entrepreneurship laid the groundwork for UNHCR expansion into the developing world in the 1960s. The high commissioner's actions also underscored the Office's determination to play a key role in steering policy discussions and the future agenda for global refugee policy.

\section{Expansion into Africa, Asia, and Beyond under Felix Schnyder and Sadruddin Aga Khan}

During the 1960s and 1970s, the Cold War extended beyond Europe into parts of the Global South. Violent decolonization, as well as post-independence civil strife and war in Africa, generated vast numbers of refugees and underscored the strategic importance of conflicts outside Europe. Both East and West vied for influence in Africa and Asia and, at the same time, tried to minimize the possibilities of their ideological and strategic opponents gaining political advantage in these regions. Throughout the Global South, the United States and UssR competed to build up local allies and, through economic aid, political support, and weapons deliveries, constructed a range of client regimes that included not only governments but also liberation movements.

The United States perceived refugee problems in developing countries as potential sources of instability that the Soviet Union could exploit for its own advantage in extending hegemony in parts of Africa and Asia. Consequently, Western governments, particularly the United States, came to perceive assistance to refugees as a central part of their foreign policy towards newly independent states, thus using foreign aid asa principal tool in this East-West struggle for influence. ${ }^{21}$ During this period, governments made little distinction between military aid, development assistance, and refugee relief aid. More importantly, because UNHCR was a donor-dependent organization, possessing no communist member states and being dominated by the West, there was little risk of multilateral refugee aid being used in ways unacceptable to the principal donor governments.

Western governments were willing politically and financially to support UNHCR's operational expansion into the developing world, because international action on the refugee issue was also now viewed as a way to deal with both a growing humanitarian issue and a potentially significant source of instability in the Global South. At the same time, the infusion of newly independent African and Asian member states in the United Nations made it possible to pass further UN General Assembly resolutions that authorized UNHCR to assist a broad category of people displaced by conflict outside Europe. UNHCR capitalized on the changing composition of the UN General Assembly and used its influence with new member states to eventually further broaden the scope and substance of its mandate.

The United States saw considerable political advantage in working through UNHCR to assist African liberation movements that might otherwise fall under Soviet and Communist Bloc influence. The United States also favoured channelling 
the great majority of its assistance to African refugee groups through multilateral agencies such as UNHCR rather than bilaterally, because Washington sought to avoid causing tensions with the Portuguese colonial authorities and the South African government with whom it had close economic and security ties. ${ }^{22}$ Thus, policy convergence between the UNHCR and the United States over refugee assistance in Africa helped pave the way for the Office's expansion beyond Europe, beginning in the 1960 s.

The increase of American support for UNHCR programs in Africa coincided with the reduction of American support for refugees in Europe during the early 196os. With the construction of the Berlin Wall in 1961, fewer numbers of Communist Bloc refugees were able to flee to West Europe. Consequently, the United States began to attach less importance to the problem of refugees in Europe and sharply cut back its financial support for two of UNHCR's main institutional rivals, ICEM and the Us Escapee Program. As a consequence, UNHCR not only enjoyed a monopoly on expertise but also had no significant operational rivals, thus increasing the Office's basis to demonstrate influence and power within the global refugee regime.

UNHCR's shift during the 1960s and throughout the 1970 s from a European organization to a global actor relied upon further proactive, entrepreneurial leadership. The two high commissioners during this period, Felix Schnyder and Sadruddin Aga Khan, were both politically astute and anticipated that the traditional concepts and legal definitions that the Office had used in Europe would not apply in the less developed countries and took innovative steps to expand the Office's global reach. Both men sought to identify opportunities in the changing nature of world politics during this period that would justify a more formal global role for UNHCR.

For Schnyder, national liberations struggles, decolonization, post-colonial independence, and the rapid expansion of the UN system during this period offered such opportunities. As former Swiss ambassador to the UN in New York and as chairman of UNHCR's Executive Committee under Lindt, Schynder had close personal relations with many delegates from the new African and Asian states at the UN General Assembly and recognized UNHCR's potential to lead in influencing the future direction of global refugee policy.

The third high commissioner took initiatives to steer government discussions at the UNHCR General Assembly and within the Office's Executive Committee towards a greater understanding of the challenges presented by refugee movements in the Global South and the role that his Office could play in leading international responses. Schnyder made clear that he foresaw a shift in UNHCR's focus away from programs involving European refugees to an emphasis on assistance to refugees in the developing world. Using his influence with the established powerful state members and with the new member states at the UN, the high commissioner won the support of governments to authorize a series of "good offices" resolutions to respond to new refugee emergencies and to undertake new tasks. In 1961, the un General Assembly gave UNHCR the authority to assist "both refugees within the mandate and those for whom he extends his good offices."

The distinction between "good offices" and mandate refugee operations was subsequently abandoned by the UN General Assembly in 1965, formally recognizing UNHCR's competence to provide protection and permanent solutions to refugees within the UNHCR mandate and refugees covered by the high commissioner's good offices. The UN General Assembly also acknowledged the universal character of the work of UNHCR by appointing for the first time five additional members-all from North and Sub-Saharan Africa-to the Office's Executive Committee.

By the mid-196os, however, Schnyder questioned the continued utility of the good offices mechanism to address the rapidly expanding numbers of refugee situations in Africa and initiated a process to amend the geographic and temporal restrictions contained in the Refugee Convention. ${ }^{23} \mathrm{He}$ promoted discussion within his Executive Committee and among legal experts and others from the epistemic community that led to the framing and adoption of the 1967 Protocol to the 1951 Refugee Convention. The Protocol removed the Euro-centric bias of the refugee regime and created a definition of refugee applicable to a wider range of refugee situations. Consequently, the Refugee Convention was brought into line with the universal scope of UNHCR's Statute, leading the way for the further global expansion and flexibility of UNHCR activities. This UNHCR initiative was broadly supported by states and is yet another example of UNHCR's entrepreneurial role and its growing use of its agency and expertise during this period to enable the Office to exercise greater authority and expand its operational scope.

UNHCR under Sadruddin Aga Khan (who had been deputy high commissioner under Felix Schynder) initiated and capitalized on international political and humanitarian developments to progressively expand its scope and authority in global refugee policy and world politics.

In order to lay the legal groundwork for this expansion, the fourth high commissioner broadened his authority to assist a growing number of persons claiming to be refugees or in refugee-like situations through successive un resolutions. In southern Sudan, UNHCR, for the first time, assisted people who were internally displaced. In 1972, the UN General Assembly mentioned refugees and displaced persons side-by-side for the first time, and in 1975 and again in 1979 requested the high commissioner to promote lasting and 
speedy solutions for refugees and displaced persons "wherever they occur." Sadruddin interpreted these resolutions to mean that "the High Commissioner's Office could take action on behalf of large groups of people who may not all conform to conventional definition of a refugee but are in a situation analogous to that of refugees." 24

UNHCR's assumption of the role of "focal point" for the UN's humanitarian assistance efforts, which it first used in the 1971 East Pakistan crisis and later in South Sudan and Cyprus, became an acceptable international arrangement to coordinate the activities of the UN in a major humanitarian emergency when the technical and material needs would exceed the mandate of any one agency. This would be the first of many refugee crises in which successive UN secretaries-general would call upon UNHCR to act as the UN lead agency for the coordination of international humanitarian assistance not only to refugees but also to victims of humanmade disasters and in selected cases to internally displaced persons.

Under Sadruddin, UNHCR not only acted as the focal point for large-scale UN relief efforts, but also opened UNHCR offices in Asia and Latin America and administered massive repatriation programs. In the process, the Office developed an enormous agenda and became an indispensable and autonomous actor in many of the major humanitarian and political developments in Africa and Asia.

During this time, UNHCR also increased its efforts to influence the attitudes and actions of new states in Africa and Asia towards refugees. The Office's autonomy and authority derived from its status as the guardian of international refugee norms and as the holder of specialized knowledge and expertise on refugee issues. Sadruddin realized that in order for his Office to have any impact on the world political arena it had to use the power of its expertise, ideas, strategies, and legitimacy to alter the international and value contexts in which states made policy.

As high commissioner, Sadruddin sought to influence and shape state practices and to define what constituted acceptable and legitimate state behaviour in the treatment of refugees. The Office sought to convince states to define their national interests in ways compatible with refugee needs. UNHCR not only acted as a transmitter and monitor of refugee norms but also socialized new states to accept the promotion of refugee norms domestically as part of becoming a member of the international community. The political leaders of most newly independent countries in Africa and most other regions cared about their international image and sought international legitimacy through cooperation with UNHCR. Consequently, through a mixture of persuasion and socialization, the Office acquired considerable legitimacy and authority in the eyes of most new states.
At the same time, UNHCR experienced few of the kinds of asylum problems in the industrialized states that would confront the Office in later decades. Most governments acknowledged that the Office's protection division enjoyed unrivalled specialized knowledge and expertise concerning refugee and asylum law and deferred to the Office's authority on asylum policy. With the notable exception of a few states, the Office played an active role in the refugee determination procedures of several industrialized states and exerted a considerable influence over government decisions. Hence, UNHCR's autonomy was enhanced, and most governments in Western Europe demonstrated a generally liberal attitude towards asylum seekers.

Sadruddin perceived his Office to be first among equals within the un humanitarian agencies. The Office's expansion under his tenure coincided with a period of institutional crisis within ICEM. By the early 1970s, ICEM no longer had large numbers of European refugees and migrants to transfer overseas. Most donor states no longer saw the need for new ICEM programs, and several withdrew their membership, thereby further strengthening UNHCR's position within the international humanitarian system.

Similarly during the 1970s, as UNHCR activity extended to relief programs involving both human-made and natural disasters, the Office directly competed with the operations of the newly established Office of the United Nations Disaster Relief Coordinator. UNHCR sought to maintain control over its operations regarding the large-scale disasters of the period and thereby greatly expanded the functions, size, and budget of his Office. By 1976, the un Economic and Social Council confirmed UNHCR's new coordinating function as an integral part of its enlarged competence when it requested the high commissioner "to continue its cooperation with governments, Un bodies, appropriate inter-governmental organisations and voluntary agencies, to alleviate the suffering of all those of concern to his Office." 25 The same resolution identified persons of concern to be "refugee and displaced persons, victims of human-made disasters, requiring urgent humanitarian assistance."

The exponential expansion of the Office's activities during the mid-1970s led to a substantial increase in the size of UNHCR staff, its working budget, and above all the amount of funds spent on assistance programs. Annual program expenditure, which amounted to \$3-4 million in the early 196 os to $\$ 8.3$ million at the beginning of the 1970 , leapt to $\$ 69$ million in $1975 .{ }^{26}$ In addition to its regular activities, the UNHCR also acted as coordinator or the focal point for UNwide humanitarian and development assistance programs, sometimes involving budgets in the hundreds of millions of dollars. Consequently, the UNHCR's special operations budget in 1975 had grown thirty-fold since 1966 as it coordinated 
massive repatriations and UN assistance programs throughout the developing world. Big budgets reflected the international community's confidence in the UNHCR's ability to carry out refugee relief programs and to be the primary humanitarian actor in the global arena.

This remarkable growth in both the size and diversity of UNHCR policies and programs and in its ability to define and influence the shape of international refugee norms and practice during a period of global change and upheaval supports the view that international organizations such as UNHCR frequently exhibit considerable autonomy, influence, and in selective circumstances even power, and that states are not the only important actors in international relations.

\section{Lessons of History}

UNHCR and states have been too quick to forget the remarkable early history of the Office and have not recognized the need to revisit the period for guidance. This was a time when UNHCR was at its weakest in material power and capabilities. Yet this was a period when the Office exercised influence and even power in selective circumstances over states and other actors in the international system.

During the first half of UNHCR's history, the Office demonstrated the importance of a strong foundation of international norms and of effective and innovative leadership and entrepreneurship from individual high commissioners. In navigating the Cold War and the period of decolonization and conflict in the developing world, UNHCR had confidence in its strategic purpose and was aware of the changing global political context as well as the particular impact of their decisions upon the Office's response to displacement in the developing world. ${ }^{27}$ The Office was at its most successful when individual high commissioners and individual members of staff played a leadership role and were encouraged to be creative in identifying solutions to particular problems.

The role of individuals in UNHCR's early history and the leadership provided from the Office's first four high commissioners were essential to its success and influence during this period. All of these leaders had a un political background, which increased the likelihood that they would be successful, particularly since the Office relied on the support of the UN secretaries-general and the UN General Assembly to expand its operations and authority. This contrasted with the second half of UNHCR history when states largely appointed high commissioners who had been involved in state politics and who had little prior experience with the United Nations and UNHCR.

Goedhart had served as the Netherlands delegate to the fourth and fifth sessions of the UN General Assembly. Most significantly, he had chaired the Third Committee, which had overseen the creation of UNHCR. Goedhart was elected in 1950 by the UN General Assembly, despite strong opposition of the United States, who backed their own candidate, Donald Kingsley, the head of the IRO. A strong orator and persuasive public speaker, Goedhart was widely admired for his firm commitment to human rights and refugee causes.

Similarly, before becoming the second high commissioner, Auguste Lindt had prior experience with the UN General Assembly in New York as Swiss ambassador. He was a personal friend of Dag Hammarskjöld, the un secretarygeneral, and on good terms with the us delegation. Having a strong personality and a determined approach to difficult problems, Lindt was a pragmatic and skilled diplomat who oversaw UNHCR's initial expansion beyond Europe.

Like Lindt before him, Felix Schnyder had served as Swiss ambassador to the UN in New York at a time of transition at the organization with the rapid growth of new member states at the Un during a period of decolonization. The third high commissioner had close personal relations with many delegates from Africa. Schnyder chaired UNHCR's Executive Committee under Lindt and therefore arrived at UNHCR with a firm understanding of both the organization and of global refugee policy.

Sadruddin Aga Khan had extensive prior experience of UNHCR before becoming the fourth high commissioner. Sadruddin served previously as Schynder's deputy high commissioner. As a leader in the Ismaeli community, Sadruddin had strong international connections and reflected the shift in UNHCR concern from Europe to the entire Global South at that time. As high commissioner, Sadruddin pursued a similar path of expansion of UNHCR's global reach, as had his predecessors.

During this period of its history, the first four high commissioners exercised influence and even power on global refugee policy, not only through individual leadership but also the unrivalled moral authority granted to the Office by its monopoly on legal expertise. At the time UNHCR was created, the entire legal unit at the International Refugee Organization moved to UNHCR and formed the UNHCR legal protection bureau. Paul Weiss, Jacques Colmar, Michael Mousalli, and others had unmatched legal and moral expertise on global refugee matters. States did not have this level of expertise and moral authority, and neither did ICEM, USEP, or other international and regional organizations. During the second half of UNHCR's history, many states developed their own legal expertise and had their own networks to counter UNHCR and to create alternative policies.

The UNHCR was originally created as a small office of 33 persons and expanded only incrementally over the next few decades. ${ }^{28}$ By 1953 , the Office had 99 persons, ${ }^{29}$ and during the first two decades of its history the size of staff increased very gradually. From 1959 to 1972, the number of staff barely 
increased from 242 to $322 .{ }^{30}$ As a small tight-knit group of UN professionals, UNHCR developed a strong institutional culture and identity through a system of informal mentoring of junior staff by UNHCR senior members. This contributed greatly to the overall effectiveness of the Office during this period. From the late 1970 on on, however, UNHCR grew rapidly, and by 31 October 2016 the Office had 10,700 staff located in 128 countries, which made mentoring of individual staff impossible. ${ }^{31}$

Drawing upon the insights of UNHCR's past adaptation to regional and global changes during the first half of its history, this article underscores the importance of the Office continuing to be flexible and catalytic in an increasingly changing and complex global refugee environment. Throughout the past sixty-five years, the Office has had to reinterpret its role in global refugee policy. At each stage, UNHCR has faced the imperative of ensuring refugees' access to protection and solutions, safeguarding its own organizational interests, and maintaining its relationship with states. In the future, the Office can draw important lessons from the protectionfocused, assertive, and strategic agenda of its early years. While the context may be different, the basic principles for success remain as relevant as ever.

The Office today is confronted with a world radically changed from the one it first entered in the early 1950 s and faces new and emerging challenges, including migration, urbanization, state failure and fragility, climate change, and redefining the protection and assistance environment in which it works. Institutionally it faces an increasingly dense global environment in which a range of other international and regional organizations potentially compete with UNHCR and enable states to bypass the Office in addressing their concerns regarding asylum and migration. Politically, in both the Global North and Global South, populism, prejudice, and ethnic, religious, and political intolerance are on the rise. Xenophobia and fear, driven in part by hostility to migrants and refugees, are present in many former host countries and have been exacerbated by the growth and impact of social and political media. Protection and asylum space are diminishing, and UNHCR faces the challenge of how to reinvigorate states' commitment to refugees and other displaced populations. In recent years, the emergence of a more fragmented international politics with several power centres has put new pressures on the previous international consensus of rules and norms governing state behaviour and the roles of international organizations. Countries such as India, China, Brazil, and a number of Arab countries have become more engaged in international development and humanitarian aid, while UNHCR continues to depend exclusively on voluntary rather than mandatory funding provided mostly by North American and European governments and Japan.
In responding to these problems and developments, UNHCR can learn important lessons from its early history and develop the capacity to address these and future challenges by strengthening its capability to engage in new policy fields, building new partnerships within and beyond the UN system, and engaging strategically with the changing political context within which it works.

A new UN high commissioner for refugees was appointed in 2016. Filippo Grandi has had long experience with the UN, in senior positions at UNHCR under Sadako Ogata in the 1990 s and more recently as the head of the United Nations Relief and Works Agency for Palestinian refugees. His recent appointment as the eleventh UNHCR high commissioner coincides with major new and protracted refugee crises in Europe, the Middle East, Africa, and Asia. As in earlier decades of UNHCR history, the global response to the current refugee crises requires strong leadership from the high commissioner and the international community. As in earlier refugee crises, Grandi must frame the issues at stake for his Office, for concerned states and for the refugees and displaced people under his mandate, and devise mutually acceptable formulas and policies to resolve the many crises, broker the interests of key players in building support for these policies, and exercise leadership during the implementation of any future international policy. UNHCR will also require the strong political support of both the new UN secretary-general, Antonio Guterres, and Canada and other governments on UNHCR's Executive Committee.

UNHCR's early history highlights the fact that the Office was conceived to be adaptable and entrepreneurial and to evolve in changing circumstances. Over the past six and a half decades, UNHCR has constantly adapted the scope of its concern and of its activities, demonstrating that, far from being fixed, the Office's mandate to provide protection and solutions for refugees can and should be interpreted within its historical and political context. During most of the first half of its history, adaptation was characterized by being protection-focused, assertive, and strategic. As the lead agency in refugee affairs and as the foremost expert on refugees and displaced persons, the Office exerted power and authority. UNHCR should face current new challenges by drawing confidently on these lessons and strengths from its past.

\section{Notes}

1 A. Betts and G. Loescher, eds., Refugees in International Relations (Oxford: Oxford University Press, 2011); and Bob Reinalda and Bertjan Verbeek, "Leadership of International Organizations," in The Oxford Handbook of Political Leadership, ed. R.A.W. Rhodes and Paul 'Hart (Oxford: Oxford University Press, 2014), 595-612. 
2 G. Loescher, UNHCR and World Politics: A Perilous Path (Oxford: Oxford University Press, 2001).

3 M. Barnett and M. Finnemore, Rules for the World: International Organizations in World Politics (Ithaca, NY: Cornell University Press, 2004); M. Barnett and M. Finnemore, "The Power of Liberal International Organizations," in Power in Global Governance, ed. M. Barnett and R. Duvall, 161-84 (Cambridge: Cambridge University Press, 2005); Barnett and Finnemore, "The Politics, Power and Pathologies of International Organizations," International Organization 53, no. 4 (2005): 699-732; J. Milner, "Understanding Global Refugee Policy," Journal of Refugee Studies 27, no. 4 (2014): 477-94.

4 M. Barnett and M. Finnemore, Rules for the World; Loescher, UNHCR and World Politics; Loescher, "UNHCR and World Politics: State Interests vs. Institutional Autonomy," International Migration Review 35 (Spring 2001): 33-56; A. Betts, "UnHCR, Autonomy and Mandate Change," in International Organizations as Self-Directed Actors, ed. Joel Oestreich, 118-40 (Abingdon, va: Routledge, 2013).

5 J. Elie, "The Historical Roots of Cooperation between the un High Commissioner for Refugees and the International Organization for Migration," Global Governance 16 (2010): 345-6o; M. Geiger and A. Pecoud, eds., The Politics of International Migration Management (Basingstoke, uK: Palgrave Macmillan, 2010); M. Geiger and A. Pecoud, "International Organizations and the Politics of Migration," Journal of Ethnic and Migration Studies 40, no. 6 (2014): 865-87.

6 Elie, "Historical Roots of Cooperation."

7 Loescher, UNHCR and World Politics.

8 M. McBride, "Anatomy of a Resolution: The General Assembly in UNHCR History," New Issues in Refugee Research, Research Paper No. 182, UnHCR, Geneva, December 2009; L. Holborn, Refugees: A Problem of Our Time-The Work of the United Nations High Commissioner for Refugees, 19511972, vols. 1 and 2 (Metuchen, NJ: Scarecrow, 1975).

9 Cited in P. Orchard, A Right to Flee: Refugees, States and the Construction of International Cooperation (Cambridge: Cambridge University Press, 2014), 179.

10 M. Gottwald, "Directive vs Facilitative Leadership in Times of Change: UnHCR's Organizational Culture and DecisionMaking Process in Light of Humanitarian Reform and the Cluster Approach" (paper prepared for the conference "Protecting People in Conflict and Crisis: Responding to the Challenges of a Changing World," Refugee Studies Centre, University of Oxford, 22-4 September 2009); Loescher, UNHCR and World Politics.
11 Elie, "Historical Roots of Cooperation."

12 Loescher, UNHCR and World Politics.

13 P. Gatrell, Free World? The Campaign to Save the World's Refugees, 1956-1963 (Cambridge: Cambridge University Press, 2011).

14 M. Keck and K. Sikkink, Activists beyond Borders: Advocacy Networks in International Politics (Ithaca, NY: Cornell University Press, 1998).

15 Gatrell, Free World?, 204.

16 Cecilia Ruthstrom-Ruin, Beyond Europe: The Globalization of Refugee Aid (Lund: Lund University Press, 1993); and Loescher, UNHCR and World Politics.

17 Author's interviews with Bernard Alexander, senior adviser to Auguste Lindt, Great Hasely, UK, December 1986; Gilbert Jaeger, Oxford, 1986; and Fonds Interview of August Lindt, 24 January 1998, 36 Record of the Archives, sound recording.

18 U.S. National Archives, Diplomatic Branch, 320, 42/6 S57, 5 June 1957.

19 Author's interview with Bernard Alexander UNHCR chief of staff for Lindt, Great Hasely, UK, December 1986.

20 Loescher, UNHCR and World Politics, 100.

21 Ibid.; and Ruthstrom-Ruin, Beyond Europe.

22 Loescher, UNHCR and World Politics, 126-8.

23 Ibid;; Orchard, Right to Flee.

24 Loescher, UNHCR and World Politics.

25 ECOsOC Resolution 2011, 2 August 1976.

26 Loescher, UNHCR and World Politics.

27 Betts, "UnHCr, Autonomy and Mandate Change"; and A. Betts, G. Loescher, and J. Milner, UNHCR: The Politics and Practice of Refugee Protection, 2nd ed. (Abingdon, va: Routledge, 2012).

28 UNHCR, Review of UNHCR's Project Staff Arrangements, Inspection and Evaluation Service, EvAL/07/97, Geneva 1997, para. 25, cited in Elie, "Historical Roots of Cooperation," 345-60.

29 Ibid.

30 Ibid.

31 "Figures at a Glance," UNHCR, 31 October 2016, http://www .unhcr.org/figures-at-a-glance.html.

Gil Loescher is visiting professor at the Refugee Studies Centre in the Department of International Development Studies at the University of Oxford, and emeritus professor of political science at the University of Notre Dame in the United States. The author may be contacted at gilloescher@gmail.com.

(C) Gil Loescher, 2017. This open-access work is licensed under a Creative Commons Attribution-NonCommercial 4.0 International License, which permits use, reproduction and distribution in any medium for non-commercial purposes, provided the original author(s) are credited and the original publication in Refuge: Canada's Journal on Refugees is cited. 